\title{
PARTISIPASI MASYARAKAT DALAM KEGIATAN PEMBANGUNAN JALAN PERTANIAN DI AERTRANG KELURAHAN MALALAYANG I TIMUR MANADO
}

\author{
Isaura Gabriela Engka \\ Charles R. Ngangi \\ Caroline B. D. Pakasi
}

\begin{abstract}
The purpose of this research is to know the forms of community participation of farmers and nonfarmers in the Agricultural Road construction Aertrang Malalayang 1 East Village in the Manado City. The benefits of this research are: research is expected to provide information for the public and education about the forms of participation of farmers and non-farmers in agriculture road construction in the Village of Aertrang Malalayang 1, Manado City. This research collect primary dan secondarydata. Primary data collection through direct face to face interviews and field observations (observation) to 20 respondents using questionnaires. The analytical method used in this research is qualitative descriptive analysis method. The results of the study are presented in tabular form. The findings in this study are: (1) The forms of community participation in development activities of agricultural roads in the village Malalayang I Aertrang East, namely: labor, money, materials such as cement, stone and sand. And also, provision of consumption / food to the community members who do the work of farm road construction, (2) community members actively involved in agricultural road construction activities in the Village Malalayang I Aertrang East.
\end{abstract}

Key words: Community participation, farm road construction, Manado City

\begin{abstract}
ABSTRAK
Tujuan penelitian ini yaitu mengetahui bentuk-bentuk partisipasi masyarakat petani dan non-petani dalam pembangunan Jalan Pertanian Aertrang Kelurahan Malalayang 1 Timur di Kota Manado. Manfaat dari penelitian ini yaitu : Penelitian ini diharapkan dapat memberikan informasi bagi masyarakat dan dunia pendidikan tentang bentuk-bentuk partisipasi masyarakat petani dan non petani dalam pembangunan Jalan Pertanian Aertrang di Kelurahan Malalayang 1 Timur Manado. Data yang dikumpulkan dalam penelitian ini adalah data primer dan sekunder. Metode pengumpulan data primer yaitu lewat wawancara tatap muka secara langsung dan pengamatan lapangan (observasi) kepada 20 orang reponden dengan menggunakan daftar pertanyaan. Data sekunder dikumpulkan dari dokumen yang berasal dari Kantor Desa. Metode analisis yang digunakan dalam penelitian ini adalah metode analisis deskriptif kualitatif, yang hasil penelitian disajikan dalam bentuk tabel. Penemuan dalam penelitian ini adalah (1) Bentuk-bentuk partisipasi masyarakat dalam kegiatan pembangunan jalan pertanian Aertrang di Kelurahan Malalayang I Timur yaitu: tenaga krtjs, dana, bahan material berupa semen, batu dan pasir. Serta pemberian konsumsi/makanan kepada masyarakat yang melakukan pekerjaan pembangunan jalan pertanian, (2) Masyarakat terlibat aktif dalam kegiatan pembangunan jalan pertanian Aertrang di Kelurahan Malalayang I Timur.
\end{abstract}

Kata Kunci: Partisipasi Masyarakat, pembangunan jalan pertanian, Kota Manado 


\section{PENDAHULUAN}

\section{Latar Belakang}

Kegiatan pembangunan yang dari dahulu sampai saat ini yang diterapkan oleh masyarakat yaitu dengan melakukan gotong royong atau kerjasama antar masyarakat guna mewujudkan suatu pembangunan yang diharapkan. Kegiatan pembangunan yang tertumpu kepada masyarakat dengan melibatkan sebesar mungkin peran masyarakat mulai dari perencanaan, pelaksanaan, pembiayaan, hingga monitoring dan perkembangannya. Pendekatan ini dimulai dengan keikutsertaan masyarakat sebagai pelaku utama dalam proses perencanaan pembangunan karena masyarakat di yakini paling mengetahui dan memahami segala kebutuhan, pola pikir, sistem nilai, perilaku dan adat istiadat serta kebiasaan di lingkungannya.

Pembangunan yang efektif membutuhkan keterlibatan (partisipasi) awal dan nyata di pihak semua pemangku kepentingan (stakeholders) dalam penyusunan rancangan kegiatan yang akan mempengaruhi mereka. Sewaktumasyarakat yang terlibat merasa bahwa partisipasimereka penting, mutu, efektifitas dan efisiensi pembangunan akan meningkat. Bentuk partisipasi yang merupakan wujud kontribusi masyarakat untuk ikut terlibat dalam kegiatan pembangunan sangat variatif. Untuk alasan penyederhanaan sebagai indikator besaran partisipasi masyarakat dapat diklasifikasikannya berdasarkan wujud konkrit yaitu kontribusi berbentuk natura dan berbentuk innatura. Bahwa bentuk partisipasi masyarakat yang berwujud natura lebih mudah terukur secara kuantitas karena dampaknya dapat dirasakan secara langsung.Sebaliknya, bentuk partisipasi masyarakat yang berwujud innatura perlu pemahaman yang lebih mendalam untuk dapat mengukurnya secara kualitas.

Kegiatan pembangunan suatu daerah baik itu nasional, provinsi, kabupaten/kota, kecamatan bahkan kelurahan/desa, tentunya membutuhkan peran serta/partisipasi masyarakat.Masyarakat memiliki peranan yang sangat penting dalam suatu kegiatan pembangunan. Pembangunan yang baik akan memberikan ruang kepada masyarakat untuk bisa menyalurkan partisipasinya sehingga pemba- gunan yang dilakukan hanya oleh dan untuk masyarakat.

Dalam hal ini, partisipasi masyarakat pun berbeda-beda, di sebabkan oleh pekerjaan masyarakat yang ditekuni.Di suatu kelurahan/desa dalam kegiatan pembangunan ada masyarakat yang berprofesi sebagai petani ada juga yang non petani.Di Kelurahan Malalayang I Timur ini, pembangunan jalan pertanian aertrang, tidak hanya dilakukan oleh seluruh masyarakat yang ada, bukan hanya berprofesi sebagai petani, tetapi mereka juga yang non petani.Di dalam pembangunan jalan pertanian ini, setiap masyarakat menjadi sumber dan pelaku kegiatan penbangunan.Partisipasi masyarakat menjadi tolok ukur keberhasilan pembangunan Jalan Pertanian ini.Dalam pelaksanaan pembangunan jalan pertanian tersebut, peran serta masyarakat untuk berpartisipasi di dalamnya sudah sangat besar, hal ini ditandai dengan adanya sumbangan berupa tenaga, pendanaan, material dan sebagainya. Dalam penelitian ini, tertarik untuk melihat tingkat partisipasi masyarakat dalam pembangunan jalan pertanian.

\section{Pengertian Partisipasi Masyarakat}

Kata partisipasi berasal dari kata take a part yang mengadung arti ikut serta (Suherman dan Wagiyo, 2005). Definisi partisipasi sendiri begitu beragam dan luas, tergantung dari mana melihatnya.Namum secara umum dapat dikatakan bahwa partisipasi indentik dengan keikutsertaan, ambil bagian atau keterlibatan partisipan dalam kegiatan pihak lainnya. Namun demikian sangat penting untuk mengetahuhi pengertian yang telah didefinisikan kata partisipasi oleh peneliti - peneliti sebelumnya antara lain sebagai berikut:

1. Sawitri D (2006); partisipasi adalah memberikan kesempatan yang lebih besar pada masyarakat umum untuk mengambil bagian dalam proses untuk menentukan tindakan - tindakan yang akan mempengaruhi kehidupan mere$\mathrm{ka}$

2. Upholf (1992) dan Paul (1987); partisipasi masyarakat adalah "gerakan" masyarakat untuk terlibat dalam proses pembuatan keputusan, dalam pelaksanaan kegiatan, ikut menikmati hasil dari kegitan tersebut dan ikut serta dalam men- 
gevaluasinya, selain itu partisipasi masyarakat juga merupakan sebuah proses aktif dimana masyarakat dapat mempengarui arah dan pelaksanaan dari pembangunan dengan maksud untuk meningkatkan kesejahteraan mereka dalamarti penghasilan, perkembangan pribadi, kemandirian, serta berbagai nilai yang mereka yakini.

3. Menurut White Sastropoetro, 1988); keikut sertaan atau partisipasi masyarakat adalah keterlibatan komunitas setempat secara aktif dalam pengambilan keputusan atau pelaksanaanya terhadap proyek-proyek pembangunan untuk masyarakat.

4. Menurut Keith Davis Sastropoetro, (1988); partisipasi adalah keterlibatan mental atau pikiran dan emosi seseorang dalam situasi kelompok yang mendorongnya untuk memberikan sumbangan kepada kelompok dalam usaha mencapai tujuan serta turut bertanggung jawad terhadap usaha yang bersangkutan.

5. Korten (1986); partisipasi adalah suatu tindakan yang mendasar untuk bekerjasama. Kerjasama tersebut memerlukan waktu dan usaha agar menjadi mantap dan hanya bisa berhasil baik dan terus menerus maju bila ada kepercayaan bersama.

Menurut Tjondronegoro (1990). Ada beberapa arti kata partisipasi adalah:

1. Partisipasi adalah kontribusi sukarelah dari masyarakat kepada proyek tanpa ikut serta dalam pengambilan keputusan.

2. Partisipasi adalah 'pemekaan' (membuat peka) pihak masyarakat untuk meningkatkan kemauan menerima dan kemampuan untuk menanggapi proyek - proyek pembangunan.

3. Partisipasi adalah suatu proses yang aktif yang mengandung arti bahwa orang atau kelompok yang terkait, mengambil inisiatif dan menggunakan kebebasannya untuk melakukan hal itu.

4. Partisipasi adalah pemantapan dialog antara masyarakat setempat dengan para staf yang melakukan persiapan, pelaksanaan, monitoring proyek, agar supaya memperoleh informasi mengenai konteks lokal dan dampak-dampak sosial.
5. Partisipasi adalah keterlibatan sukarela oleh masyarakat dalam perubahan yang ditentukan sendiri.

6. Partisipasi adalah keterlibatan masyarakat dalam pembangunan diri, kehidupan dan lingkungan mereka.

Dalam hal ini terdapat dua jenis definisi partisipasi yang beredar di masyarakat.Definisi pertama adalah definisi yang diberikan oleh para perencana pembangunan formal di Indonesia, yang mengartikan partisipasi rakyat dalam pembangunan sebagai dukungan rakyat terhadap rencana/proyek pembangunan yang dirancang dan ditentukan tujuannya oleh perencana. Ukuran tinggi rendahnya partisipasi diukur dengan kemauan rakyat ikut menanggung biaya pembangunan, baik berupa uang maupun tenaga dalam melaksanakan proyek pembangunan pemerintah. Sedangkan definisi kedua, dan berlaku universal adalah bahwa partisipasi rakyat dalam pembangunan merupakankerjasama yang erat antara perencana dan rakyat dalam merencanakan, melaksanakan, melestarikan dan mengembangkan hasil pembangunan yang telah dicapai.

Ukuran tinggi rendahnya partisipasi rakyat dalam pembangunan tidak hanya diukur dengan kemauan rakyat untuk menanggung biaya pembangunan, tetapi juga dengan ada tidaknya hak rakyat untuk ikut menentukan arahan dan tujuan proyek yang akan dibangun di wilayah mereka. Selain itu juga diukur berdasarkan ada tidaknya kemauan rakyat untuk secara mandiri melestarikan dan mengembangkan hasil proyek itu.Dari sudut pandang sosiologis, definisi pertama tidak dapat dikatakan sebagai partisipasi rakyat dalam pembangunan melainkan mobilisasi rakyat dalam pembangunan.Mobilisasi rakyat dalam pembangunan hanya dapat mengatasi permasalahan pembangunan dalam jangka.

\section{Bentuk Partisipasi Masyarakat}

Bentuk partisipasi masyarakat merujuk pada wujud kontribusi masyarakat dalam keikutsertaannya. Wujud kontribusi dari partisipasi masyarakat sudah barang tentu tergantung pada tahapan proses pelaksanaan program, karena wujud kontribusi tersebut akan berbeda pada setiap tahapan. Misalkan dalam tahapan partisipasi pada 
pengambilan keputusan, maka wujud kontribusi dari partisipasi masyarakat berupa sumbangan pemikiran dimana yang menjadi tolak ukurnya adalah banyaknya usul dan saran atau bahkan penolakan. Hal yang sama dikatakan oleh Cohen dan Uphoff bahwa wujud dari partisipasi masyarakat dalam pengambilan keputusan itu bisa bermacammacam seperti: kehadiran dalam rapat, diskusi, sumbangan pemikiran,tanggapan atau penolakan terhadap program yang ditawarkan.

Melihat dari tahapan pelaksanaan pembangunan, dimana partisipasi terbagi atas partisipasi langsung dan tidak langsung.partisipasi secara langsung berarti anggota masyarakat tersebut ikut memberikan bantuan tenaga dalam kegiatan yang dilaksanakan, misalnya dalam proyek pembangunan jalan, anggota masyarakat ikut serta dalam pekerjaan membangun jalan tersebut. Sedang partisipasi secara tidak langsung berupa bantuan dana dan material yang diperlukan.

Secara keseluruhan tahapan, dimana bentuk-bentuk partisipasi masyarakat dapat berupa: (1) sekedar memanfaatkan layanan, (2) memberikan sumbangan, (3) kehadiran dalam pertemuan, (4) konsultasi, (5) keterlibatan dalam menyampaikan layanan, (6) keterlibatan dalam implementasi, dan (7) peranserta dalam semua tahapan pembuatan keputusan, yakni identifikasi masalah, studi kelayakan, pelaksanaan, dan evaluasi. Hal yang sama juga diutarakan oleh Keith Davis (dalam Sastropoetro, 1988) yaitu dengan menggolongkan bentuk partisipasi menjadi lima bentuk yaitu: 1) partisipasi buah pikiran; 2) partisipasi keterampilan/keahlian; 3) partisipasi tenaga; 4) partisipasi harta benda dan; 5) partisipasi Uang, sejalan dengan kegiatankegiatan yang dapat digolongkan sebagai partisipasi adalah ikut mengajukan usul-usul mengenai suatu kegiatan, ikut serta bermusyawarah dalam mengambil keputusan tentang alternatif program yang dianggkap paling baik, ikut serta melaksanakan apa yang telah diputuskan termasuk disini memberi iuran atau sumbangan materiil dan terakhir ikut serta mengawasi pelaksanaan keputusan.

Wujud kontribusi partisipasi masyarakat sudah barang tentu tergantung pada tahapan pelaksanaan program, karena wujud kontribusi tersebut akanberbeda pada setiap tahapan. Adapun variasi bentuk partisipasi masyarakat dalam fase pelaksanaan program pembangunan infrastruktur desa dapat diuraikan dalam Tabel 1

Tabel 1. Bentuk Partisipasi menurut Fase

\begin{tabular}{cl}
\hline Fase & \multicolumn{1}{c}{ Bentuk Partisipasi } \\
\hline Perencanaan & 1. Kehadiran dalam rapat \\
& $\begin{array}{l}\text { 2. Sumbangan pemikiran } \\
\text { dalam pengambilan kepu- } \\
\text { tusan }\end{array}$
\end{tabular}
Pelaksanaan
1. Tenaga
2. Pendanaan
3. Tanah pekarangan
4. Material

$\begin{array}{ll}\text { Pemanfaatan dan } & \text { 1. Tenaga } \\ \text { pemeliharaan } & \text { 2. Pendanaan } \\ & \text { 3. Material }\end{array}$

Monitoring Evaluasi 1. Ide/Pemikiran

2. Pengawasan

\section{Sumber: Dien 2012}

\section{Tingkat Partisipasi Masyarakat}

Tingkat partisipasi yang dilihat dari besaran kerelaan atau keiklasan dari partisipasi (masyarakat) dapat dibedakan menjadi dua yaitu partisipasi asli dan semu.Partisipasi asli mengandung makna adanya kerelaan dan keterlibatan masyarakat secara demokratis, pembagian manfaatsecara adil, kebersamaan dalam ketetapan tujuan, kebijakan, perencanaan dan implementasi. Bila keterlibatan masyarakat pada implementasi kebijakan dibatasi, penetapan keputusan oleh pihak luar atau ditentukan oleh pemerinta, maka partisipasi yang dilakukan merupakan partisipasi semu. Selain itu ciri partisipasi asli adalah tumbuh dari bawah (grassroots), berfokus pada pendistribusian kue pembangunan secara merata, berfunsi untuk mempertinggi kesadaran terhadap kemampuan sendiri dan percaya bahwa partisipan dapat mempengaruhi hasil (Hetifa Sj Sumarto, 2003).Lain halnya dengan Dusseldorp yang mana membagi tingkatan partisipasi menjadi tiga kelompok yang didasarkan 
atas derajat kesukarelaannya, yaitu: 1) partisipasi spontan; 2) partisipasi terbujuk dan 3) partisipasi terpaksa. Partisipasi spontan; terjadi bila masyarakat secara serta-merta mulai berpartisipasi berdasarkan pada keyakinan tanpa dipengaruhimelalui penyuluhan atau ajakan oleh lembaga-lembaga lain. Partisipasi terbujuk, yaitu bila masyarakat mulai berpartisipasi setelah diyakinkan melalui program penyuluhan atau oleh pengaruh lain. Partisipasi terpaksa dapat terjadi dalam berbagai cara, misalnya terpaksa oleh hukum, terjadi bilah orang-orang dipaksa melalui hukum atau peraturan untuk berpartisipasi dalam kegiatan tetapi bertentangan dengan keyakinan mereka atau tanpa melalui persetujuan mereka.

Tingkatan partisipasi tidak berdasarkan derajad kerelaan masyarakat tetapi melihat sejauh mana peran pemerintah dalam proses pelaksanaan program. Nieras dkk mengidentifikasikan tingkatan partisipasi masyarakat ke dalam tingkatan sebagai berikut:

1. Consultation, pemerintah mendengar secara langsung kebutuhan dan permintaan warga

2. Presence dan Representation, pemerinta tidak hanya mendengar, tetapi mulai secara nyata bekerja dengan warga

3. Influence, pemerintah mulai menghasilkan output nyata.

Meskipun tujuan akhir dari semua program yang diperuntukkan bagi masyarakat adalah sama yaitu dalam rangka peningkatan kesejahteraan masyarakat, namun partisipasi merupakan sesuatu yang berbeda jika dilihat dari tujuan antara yang diharapkan. Pada program-program pemberdayaan masyarakat (community development), partisipasi masyarakat dipadang sebagai tujuan antara.Sedangkan pada program-program pembangunan inirastruktur desa, partisipasi dipandang sebagai instrumen guna mewujudkan infrastruktur yang benar-benar dibutuhkan oleh masyarakat.

Pembangunan infrastruktur merupakan tugas dan kewajiban pemerintah dalam penyediaannya.Untuk itu membagi tingkatan partisipasi berdasarkan kerelaan.Berdasarkan peran dan wewenang yang ada masyarakat sebagai partisipan.Wewenang kaitannya dengan tanggung jawab yang ada pada pemerintah.Dalam konteks ini, jika masyarakat ikut berperan dalam memberi imformasi namun pemerintah tidak memberikan wewenannya pada masyarakat untuk berkolaborasi maka partisipasi ini pada tingkatan partisipasi pasif.Sedangkan perang kaitannya dengan aksi yang dilakukan oleh masyarakat setempat mulai dari ikut bekerja dengan bayaran, ikut bekerja tanpa bayaran, memilih opsi yang diberikan, ikut merencanakan hingga merencanakan dan melaksanakan secara mandiri.

Dapat disimpulkan bahwa tingkat partisipasi merupakan sebuah alat ukur untuk menilai seberapa besar perang dan wewenang yang ada pada sisi masyarakat.Semakin besar peran dan wewenang yang ada pada masyarakat maka semakin tinggi tingkat partisipasinya, dan sebaliknya.Dalam hal ini bahwa ada dua prasyarat dalam meningkatkan partisipasi masyarakat, yaitu:

1. Adanya kemauan dari pihak yang mempunyai otoritas atau sumber kewenangan untuk mendistribusikan kewenangan pada masyarakat sebagai mitra dalam proses, dan

2. Adanya kemauan masyarakat untuk meningkatkan kapasitasnya sehingga dapat mengambil bagian dalam proses yang ada.

\section{Faktor-Faktor yang Berpengaruh Terhadap Partisipasi Masyarakat}

Meningkatkan keikutsertaan masyarakat dalam proses pembangunan merupakan sesuatu yang tidak mudah untuk dilaksanakan. Meskipun sejumlah warga atau perwakilan warga telah dapat berpartisipasi, kesulitan belum sepenuhnya diatasi. Masalah yang muncul paling tidak diawal adalah kemungkinan warga dan pemerinta tidak saling percaya satu dengan yang lain. Pada satu sisi, pemerintah meragukan keterwakilan warga yang perlu didengar pendapatnya, pada pihak lain warga meragukan motivasi pemerintah dalam melibatkan dirinya, apaka pendapatnya benar-benar diinginkan atau sekedar untuk menjual sesuatu. Faktor kepercayaan antara stakeholder adalah faktor penting dalam mendorong partisipasi warga.

Membangun serta meningkatkan motivasi dan persepsi masyarakat dalam berpartisipasi sama halnya dengan membangun kesadaran akan pentingnya hidup bersih, pentingnya pendidikan dan kegiatan-kegiatan non fisik lainnya dimana memerlukan proses dan waktu yang tidak sebentar. Ter- 
lebih lagi hingga mencapai pada tingkatan partisipasi spontan seperti yang diuraikan sebelumnya.

Menjawab pertanyaan sederhana tentang siapa yang terlibat merupakan pertanyaan awal yang esensial. Meskipun terdengar mudah untuk menjawabnya namun akan menyebabkan kerancuan bilah tidak dipahami dengan baik. Memahami karakteristik subjek yang ikut terlibat merupakan kunci dari faktor apa yang menyebabkannya ikut terlibat. Untuk itu perlu identifikasi yang matang dalam penelaahannya. Pada hakekatnya masyarakat akan dipengaruhi oleh 3 faktor dasar yang menentukan untuk tidak atau turut serta berpartisipasi dalam banyak program yang ditawarkan oleh pemerintah. Ketiga foktor dasar tersebut yaitu motivasi, persepsi dan kemampuan.

Faktor yang mempengaruhi keikutsertaannya terlibat dalam program yang ditawarkan pemerintah yaitu pada masyarakat, Ali Nurdin (2000) partisipasi bergantung pada kondisi ekonomi, sosial budaya dan keberadaan lingkungan dari masyarakat yang terlibat serta tingkat pendidikan masyarakat. Hal yang sama juga diungkapkan oleh Rietbergen J dkk, bahwa sosial assesment yang dapat digunakan para perencana untuk dapat mengetahui bagaimana masyarakat terlibat dalam pembangunan adalah faktor geografis, organisasi dan budaya lokal, ekonomi masyarakat serta sosial politik yang berkembang.

Tingginya partisipasi masyarakat dalam pembangunan infrastruktur dapat diukur dari besarnya peranserta masyarakat untuk berkontribusi.Pada kusus dimana tingkat partisipasi berbeda antara penduduk satu desa dengan penduduk di desa lainnya mengindikasikan adanya faktor-faktor yang dapat mempengaruhinya.Faktor ekonomi, sosial budaya dan geografi serta tingkat pendidikan masyarakat yang merupakan karakteristik suatu desa diidentifikasi sebagai determinannya.

\section{Rumusan Masalah}

Berdasarkan uraian di atas maka masalah dalam penelitian ini yaitu apa saja bentuk-bentuk partisipasi masyarakat petani dan non petani dalam pembangunan Jalan Pertanian Aertrang di Kelurahan Malalayang I Timur Manado?

\section{Tujuan Penelitian}

Tujuan penlitian ini yaitu mengetahui bentuk-bentuk partisipasi masyarakat petani dan non petani dalam pembangunan Jalan Pertanian Aertrang di Kelurahan Malalayang I Timur Manado.

\section{Manfaat Penelitian}

Manfaat dari penelitian ini yaitu: Penelitian ini diharapkan dapat memberikan informasi bagi masyarakat dan dunia pendidikan tentang bentukbentuk partisipasi masyarakat petani dan non petani dalam pembangunan Jalan Pertanian Aertrang di Kelurahan Malalayang I Timur, Manado.

\section{METODOLOGI PENELITIAN}

\section{Waktu dan Tempat Penelitian}

Penelitian ini akan dilaksanakan selama 3 bulan yaitu bulan agustus-oktober 2015. Tempat penelitian di GMIM Aertrang Manado.

\section{Jenis dan Sumber Data}

Jenis data yang digunakan yaitu data primer dengan melakukan wawancara langsung kepada responden.Sumber data dalam penelitian ini yaitu masyarakat dalam hal ini jemaat GMIM aertrang yang terlibat dalam pembangunan kanisha.

\section{Metode Pengumpulan Data}

Metode pengumpulan data yaitu lewat Wawancara dan pengamatan (observasi) langsung kepada 20 orang responden dengan menggunakan daftar pertanyaan.

\section{Konsep Pengukuran Variabel}

1. Karakteristik dari masyarakat

a. Umur responden adalah 25-55 Tahun

b. Pekerjaan responden adalah Petani, PNS dan Swasta

c. Tingkat pendidikan adalah SD,SMP,SMA dan PT

2. Partisipasi masyarakat dalam pembangunan jalan pertanian 
a) Aktif (3) = diukur dengan melihatnya partisipasi dalam setiap kali dilakukannya kegiatan pembangunan baik tenaga dan dana

b) Kurang aktif (2) = diukur dengan melihat partisipasi dalam kegiatan pembangunan dengan jarang/kadang terlibat dalam kegiatan pembangunan baik tenaga maupun dana.

c) Tidak aktif (1) = partisipasi masyarakat yang tidak pernah terlibat dalam kegiatan pembangunan dan tidak memberikan dalam bentuk apapun.

\section{Analisis Data}

Metode analisis yang digunakan dalam penelitian ini adalah metode analisis deskriptif kualitatif yang nantinya hasil penelitian disajikan dalam bentuk tabel.

\section{HASIL DAN PEMBAHASAN}

\section{Karakteristik Responden}

Partisipasi masyarakat dalam kegiatan pembangunan merupakan pemerataan sumbangan masyarakat baik dalam bentuk tenaga kerja, uangtunai dan atau beragam bentuk lainnya yang sepadan dengan manfaat yang akan diterima oleh masing-masig warga masyarakat.

Tabel 2. Karakteristik Responden Berdasarkan Umur (Tahun)

\begin{tabular}{ccc}
\hline $\begin{array}{c}\text { Tingkat Umur } \\
\text { (Tahun) }\end{array}$ & Jumlah & Persentase (\%) \\
\hline $25-30$ & 3 & 15 \\
$31-40$ & 8 & 40 \\
$41-50$ & 5 & 25 \\
$>51$ & 4 & 20 \\
\hline Jumlah & 20 & 100 \\
\hline
\end{tabular}

Sumber : Hasil olahan, 2015

Dalam penelitian ini jumlah responden yang diambil sebaga sampel penelitian berjumlah 20 orang. Selain aspek bentuk-bentuk pastisipasi masyarakat yang diteliti, karakteristik responden pun menjadi hal penting untuk diketahui. Berikut akan di jelaskan karakteristik responden berdasarkan umur, tingkat pendidikan dan pekerjaan.

Tabel 2 menunjukkan karakteristik responden berdasarkan umur.Persentase terbesar responden berdasarkan umur yaitu pada tingkat umur 31-40 tahan dengan jumlah responden 8 orang atau $40 \%$. Sisanya terbagi rata-rata masing-masing $25 \%$ atau 5 orang pada tingkat umur 41-50 tahun, $20 \%$ atau 4 orang pada tingkat umur $>51$ tahun dan $15 \%$ atau 3 orang pada tingkat umur 41-50 tahun. Hal ini menunjukkan bahwa responden yang menjadi sampel penelitian ini merupakan responden yang memiliki tingkat kedewasaan umur yang cukup baik dilihat dari persentase tertinggi yaitu pada tingkat umut 31-40 tahun karena berada pada usia produktif.

Tabel 3. Karakteristik Responden Berdasarkan Tingkat pendidikan (SD, SMP, SMA sederajat)

\begin{tabular}{ccc}
\hline Pendidikan & Jumlah & Persentase $(\%)$ \\
\hline SD & 0 & 0,0 \\
SMP & 5 & $25 \%$ \\
SMA & 10 & $50 \%$ \\
S1 & 5 & $25 \%$ \\
\hline Jumlah & 20 & 100,0
\end{tabular}

Sumber : Hasil Olahan, 2015

Tabel 3 menunjukkan karakteristik responden berdasarkan tingkat pendidikan.Dapat dilihat tingkat pendidikan tertinggi responden yaitu $\mathrm{S} 1$ dengan jumlah responden 5 orang atau 25\%. Jumlah responden terbanyak yaitu pada tingkat pendidikan SMA dengan persentase $50 \%$ atau 10 orang, dan sisanya 5 orang atau $25 \%$ yaitu berpendidikan SMP. Dapat dilihat bahwa tingkat pendidikan responden yang menjadi sampel penelitian sangat baik.

Tabel 4. Karakteristik Responden Berdasarkan Pekerjaan, dilihat dari profesi responden

\begin{tabular}{ccc}
\hline Pekerjaan & Jumlah & Persentase (\%) \\
\hline Petani & 7 & 35 \\
IRT & 3 & 15 \\
Guru & 4 & 20 \\
Swasta & 3 & 15 \\
Sopir & 2 & 10 \\
Tukang & 1 & 5 \\
\hline Jumlah & 20 & 100,0 \\
\hline
\end{tabular}

Sumber : Hasil olahan, 2015 
Tabel 4 menunjukkan karakteristik responden berdasarkan pekerjaan, dilihat dari profesi responden.Terdapat enam jenis pekerjaan. Persentase terbanyak yaitu $35 \%$ atau 7 orang merupakan responden dengan pekerjaan sebagai Petani; $20 \%$ atau 4 orang sebagai guru; $15 \%$ atau 3 orang masingmasing sebagai swasta dan IRT; 10\% sebagai sopir dan sisanya 5\% sebagai tukang. Dapat dilihat bahwa pekerjaan responden bervariasi.

Tabel 5. Karakteristik Responden berdasarkan Jumlah Pendapatan

\begin{tabular}{ccc}
\hline Pendapatan (Rp) & Jumlah & $\begin{array}{c}\text { Persentase } \\
(\%)\end{array}$ \\
\hline$\leq 1.000 .000$ & 10 & 50 \\
$>1.000 .000-3.000 .000$ & 6 & 30 \\
$>3.000 .000-5.000 .000$ & 3 & 15 \\
$>5.000 .000$ & 1 & 5 \\
\hline Jumlah & 20 & 100,00 \\
\hline
\end{tabular}

Sumber : Hasil olahan, 2015

Tabel 5 menunjukkan karakteristik responden berdasarkan pendapatan. Sebagian besar responden yakni $50 \%$ atau 10 orang responden berpendapatan antara $\leq 1.000 .000$. Pendapatan $>1.000 .000-3.000 .000$ terdapat 6 orang responden atau $30 \%$.Pendapatan $>3.000 .000-5.000 .000$ terdapat 3 orang atau $15 \%$ dan sisanya 1 orang berpendapatan $>5.000 .000$. Hal ini menunjukkan bahwa rata-rata tingkat pendapatan responden sudah baik dan hal ini pun ditunjang lewat pekerjaan dari responden yang

\section{Partisipasi Masyarakat Dalam Kegiatan Pem- bangunan Jalan Pertanian}

Partisipasi masyarakat dalam kegiatan pembangunan jalan pertanian merupakan unsure penting yang harus diperhatikan.Data jumlah responden dari penelitian ini menunjukkan bahwa sebagian besar masyarakat berprofesi sebagai petani.Hal ini menjadikan pembangunan jalan pertanian merupakan hal penting karena mencakup tentang perbaikan mutu hidup masyarakat banyak.

Selain itu, kemauan berpartisipasi ditentukan oleh sikap mental yang dimiliki masyarakat untuk membangun dan memperbaiki kehidupannya, yang menyangkut : sikap untuk meninggalkan nilainilai yang menghambat pembangunan, sikap terhadap penguasa atau pelaksana pembangunan pada umumnya, sikap untuk selalu ingin memperbaiki mutu hidup dan tidak cepat puas diri, sikap kebersamaan untuk dapat memecahkan masalah dan tercapainya tujuan pembangunan serta sikap kemandirian atau percaya diri atas kemampuannya untuk memperbaiki mutu hidupnya.

Dalam penelitian ini partisipasi masyarakat dalam pembangunan jalan pertanian dibagi dalam dua bagian yaitu partisipasi masyarakat petani dan non petani.bentuk-bentuk pastisipasi dari masyarakat petani dan non petani pun berbeda. Berikut akan dijelaskan bentuk-bentuk partisipasi masyarakat petani dan non petani.

Tabel 6. Persentase Bentuk-Bentuk Partisipasi Masyarakat Petani dan Non-Petani dalam Pembangunan Jalan Pertanian

\begin{tabular}{lcc}
\hline Bentuk Partisipasi & \multicolumn{2}{c}{$\begin{array}{c}\text { Persentase Partisipasi } \\
\text { Masyarakat (\%) }\end{array}$} \\
\cline { 2 - 3 } & $\begin{array}{c}\text { Masyarakat } \\
\text { Petani }\end{array}$ & $\begin{array}{c}\text { Masyarakat } \\
\text { Non-Petani }\end{array}$ \\
\hline $\begin{array}{l}\text { Memberikan tenaga } \\
\text { dan dana }\end{array}$ & 30 & 10 \\
$\begin{array}{l}\text { Memberikan Tena- } \\
\text { ga }\end{array}$ & 70 & 10 \\
$\begin{array}{l}\text { Memberikan Dana } \\
\text { Tidak Memberikan }\end{array}$ & - & 80 \\
Partisipasi & - & - \\
\hline Jumlah & 100 & 100 \\
\hline Sumber:
\end{tabular}

Sumber : Hasil olahan, 2015

Tabel 6 menunjukkan bentuk-bentuk pasrtisipasi masyarakat dalam kegiatan pembangunan jalan pertanian, baik masyarakat petani maupun masyarakat non petani. Bentuk-bentuk partisipasi masyarakat terdiri dari memberikan tenaga dan dana, memberikan tenaga, memberikan dana dan tidak memberikan partisipasi. Bentuk partisipasi memberikan tenaga dan dana paling banyak di berikan oleh masyarakat petani dengan persentase $30 \%$ sedangkan masyarakat non petan $10 \%$. Bentuk partisipasi memberikan tenaga juga terbanyak oleh masyarakat petani dengan persentase $70 \%$, sedangkan masyarakat non petani hanya $10 \%$ sedangkan untuk bentuk partisipasi memberikan dana, 
partisipasi terbanyak oleh masyarakat non petani yaitu $80 \%$.

Dalam kegiatan pembangunan jalan pertanian aertrang di Kelurahan Malalayang I Timur ini, melibatkan berbagai unsur masyarakat dengan bentuk-bentuk partisipasi yang beranekaragam.Selain bentuk-bentuk yang dijelaskan pada Tabel diatas, ada juga bentuk partisipasi dengan memberikan material atau bahan untuk pembangunan jalan, seperti semen, kerikil dan lain sebagainya.Masyarakat yang berprofesi sebagai IRT setiap harinya mengantarkan makanan kepada masyarakat yang melakukan pekerjaan pembanguna jalan.

Pembangunan jalan pertanian ini, merupakan kerjasama masyarakat Kelurahan Malalayangg I Timur, untuk mempermudah akses transportasi dan memperlancar kegiatan pertanian.Kemampuan berpartisipasi dalam masyarakat di Kelurahan Malalayangg I Timur, sudah sangat baik karena diatur lewat gotong royong dan rasa tenggang rasa. Masyarakat non-petani pun memberikan partisipasi dalam pembangunan jalan pertanian. Keragaman partisipasi dalam pemberian input menjadi penyemangat bagi masyarakat untuk melaksanakan pembangunan jalan pertanian karena ini memberikan manfaat bagi semua masyarakat.

Tabel. 7. Keaktifan Masyarakat Dalam Kegiatan Pembangunan Jalan Pertanian

\begin{tabular}{cc}
\hline Tingkat Keaktifan & Persentase (\%) \\
\hline Aktif & 80 \\
Kurang Aktif & 20 \\
Tidak Aktif & - \\
Jumlah & $\mathbf{1 0 0}$ \\
\hline
\end{tabular}

Sumber : Hasil olahan, 2015

Tabel 7 menunjukkan tingkat keaktifan masyarakat dalam kegiatan pembangunan jalan pertanian.Dapat dilihat bahwa 80\% masyarakat aktif dalam kegiatan pembangunan dan 20\% kurang aktif.Hal ini menggambarkan bahwa tingkat partisipasi masyarakat dilihat dari keaktifan masyarakat dalam kegiatan pembanguna sudah baik.Hal ini perlu di kembangkan untuk lebih baik kedepannya.
Berdasarkan bentuk-bentuk partisipasi masyarakat, maka upaya-upaya yang perlu dilakukan untuk mempertahankan kemauan masyarakat dalam berpartisipasi meliputi : pemberian kesempatan yang dilandasi oleh pemahaman bahwa masyarakat memiliki kemampuan dan kearifan tradsional kaitannya dengan pelestarian sumberdaya alam dan lingkungan hidupnya, dan bukannya pemberian kesempatan yang dilandasi oleh prasangka buruk agar mereka tidak melakukan pengrusakan; pemberdayaan yang insentif dan berkelanjutan, yang tidak saja berupa penyampaian informasi tentang adanya kesempatan yang diberikan kepada masyarakat, melainkan juga dibarengi dengan dorongan dan harapan-harapan agar masyarakat mau berpartisipasi, serta upaya yang terus menerus untuk meningkatkan kemampuannya dalam berpartisipasi.

\section{KESIMPULAN DAN SARAN}

\section{Kesimpulan}

Kesimpulan dalam penelitian ini yaitu:

1. Bentuk-bentuk partisipasi masyarakat dalam kegiatan pembangunan jalan pertanian Aertrang di Kelurahan Malalayang I Timur yaitu: memberikan tenaga dan dana, memberikan tenaga, memberikan dana.

2. Bentuk partisipasi lainnya yaitu : pemberian bahan material serta pemberian konsumsi/makanan kepada masyarakat yang melakukan pekerjaan pembangunan jalan pertanian.

3. Masyarakat terlibat aktif dalam kegiatan pembangunan jalan pertanian aertrang di Kelurahan Malalayang I Timur.

\section{Saran}

Saran dalam penelitian ini yaitu perlunya dorongan dan harapan kepada masyarakat untuk terus aktif dalam kegiatan pembangunan lewat terus dilakukannya penjelasan tentang besarnya manfaat yang akan diperoleh dari kegiatan pembangunan yang tentunya akan bermanfaat dan akan dinikmati oleh generasi mendatang. 


\section{DAFTAR PUSTAKA}

Dien. Y. 2012, Partisipasi Masyarakat Terhadap Program Nasional Pemberdayaan Masyarakat Mandiri Perdesaan Didesa Kauditan II Kecamatan Kauditan Kabupaten Minahasa Utara, Sekrpsi, Fakultas Pertanian Unsrat Manado.

Elmi, S. 2010. Partisipasi Masyarakat Dalam Pembangunan Dan Pengelolahan Prasarana Penyediaan Air Bersih Didesa Wawoosu Dan Didesa Maitewoi, Tesis. Semarang.

Kristianto, A. W. 2013, Peningkatan Partisipasi Masyarakat Dalam Pembangunan Infrastruktur Jalan (Studi Kasus Pelaksanaan Program Pembangunan Infrastruktur Pedesaan (PPIP) di Desa Campurejo Kecamatan Panceng Kabupaten Gresik).Tesis. Jakarta.

Nurdin, Ali. 2000. Manajemen Sumberdaya Manusia, Faza Media. Jakarta

Ritzer, George dan Douglas J. Goodman. 2009. Teori Sosiologi. Kreasi Wacana : Yogyakarta.

Sanderson, K. Stephen. 1993. Sosiologi Makro. Raja Grafindo Persada : Jakarta.

Sastropoetro, Santoso. 1998. Partisipasi, Komunikasi, Persuasi dan Disiplin dalam Pembangunan Nasional. Bandung: Alumni.

Slamet, 1994, Pembangunan Masyarakat Berwawasan Peran Serta, Surakarta, Sebelas Maret University Press.
Sumarto, Hetifa Sj. 2003. Inovasi, Partisipasi, dan Good Governance, Bandung: Yayasan. Obor Indonesia.

Sutami, 2009, Partisipasi Masyarakat Pada Pembangunan Prasarana Lingkungan Melalui Program Pemberdayaan Masyarakat Kelurahan (Ppmk) Di Kelurahan Marunda Jakarta Utara, Tesis, Universitas Diponegoro Semarang.

Tjondronegoro, Soediono M.P. 1990. Revolusi Hijau dan Perubahan Sosial di Pedesaan.LP3ES : Jakarta.

Suciwati, 2006, Partisipasi Masyarakat dalam Penyusunan Rencana Umum Tata Ruang Kota Pati, Tesis, Universitas Diponegoro Semarang.

Wayan S. 2013. Partisipasi Masyarakat Di Desa Bumi Rapak Kecamatan Kaubun Kabupaten Kutai Timur.eJournal Administrasi Negara.

Yuliaty. M. 2005,Partisipasi Masyarakat Dalam Memelihara Benda Cagar Budaya Di Pulau Penyengat Sebagai Upaya Pelestarian Warisan Budaya Melayu, Tesis, Universitas Diponegoro Semarang

Yulianti. Y. 2012, Analisis Partisipasi Masyarakat Dalam Pelaksanaan Program Nasional Pemberdayaan Masyarakat (PNPM) Mandiri Perkotaan Di Kota Solok, Artikel, Universitas Andalas Padang 